\title{
PENGARUH SANKSI PAJAK, KUALITAS PELAYANAN \\ FISKUS, KESADARAN PERPAJAKAN TERHADAP \\ KEPATUHAN WAJIB PAJAK ORANG PRIBADI DI KPP PRATAMA MEDAN PETISAH
}

\author{
Steven Briantoro Dawolo \\ Joana L. Saragih
}

\begin{abstract}
Abstrak
Penelitian ini bertujuan untuk mengetahui dan menganalisis pengaruh sanksi pajak, kualitas pelayanan fiskus dan kesadaran perpajakan terhadap kepatuhan untuk membayar pajak wajib pajak orang pribadi (studi kasus pada KPP Pratama Medan Petisah ). Teknik pengambilan sampel yang digunakan adalah convenience sampling dengan jumlah sampel sebanyak 100 orang responden. Data diperoleh dari hasil kuesioner. Teknik analisis data yang digunakan adalah regresi linier berganda dan pengujian hipotesis menggunakan uji $\mathrm{t}$ dan uji $\mathrm{F}$ dengan tingkat signifikansi sebesar 5\%. Hasil uji secara parsial (uji t) dan hasil uji secara simultan (uji F) menunjukkan bahwa pengaruh sanksi pajak, kualitas pelayanan fiskus dan kesadaran perpajakan mempunyai pengaruh signifikan terhadap kepatuhan membayar pajak.
\end{abstract}

Kata Kunci: Sanksi Pajak, Kualitas Pelayanan Fiskus, Kesadaran Perpajakan, dan Kepatuhan Wajib Pajak

\section{PENDAHULUAN}

Salah satu tujuan negara adalah memberikan kesejahteraan serta meningkatkan harkat dan martabat rakyatnya. Tujuan Negara Kesatuan Republik Indonesia sebagai negara merdeka dan berdaulat adalah membangun pemerintahan di segala aspek bidang kehidupan sehingga terbentuk masyarakat yang adil dan makmur berdasarkan Pancasila dan Undang-Undang Dasar 1945. Tujuan negara sebagaimana tertuang dalam Pembukaan Undang-Undang Dasar 1945 alinea IV, yaitu "melindungi segenap bangsa Indonesia dan seluruh tumpah darah Indonesia, memajukan kesejahteraan umum, mencerdaskan kehidupan bangsa, dan ikut melaksanakan ketertiban dunia". Untuk mewujudkan tujuan tersebut, diperlukan pembangunan yang adil dan merata di segala aspek pemerintahan baik di pusat maupun di daerah. Pembangunan tersebut memerlukan modal yang cukup besar yang sumber penerimaannya dapat berasal dari berbagai sektor yakni internal dan eksternal.

Sumber penerimaan internal pemerintah salah satunya dapat berasal dari sektor pajak sedangkan sumber penerimaan eksternalnya dapat berasal dari pinjaman luar negeri. Untuk mengurangi ketergantungan akan penerimaan eksternal, Pemerintah berupaya meningkatkan penerimaan 
internalnya yakni menggali potensi pajak. Sesuai dengan Ketentuan UU KUP Pasal 1 yang berbunyi "Pajak adalah kontribusi wajib kepada negara yang terutang oleh orang pribadi atau badan yang bersifat memaksa berdasarkan Undang-Undang dengan tidak mendapatkan imbalan secara langsung dan digunakan untuk keperluan negara bagi sebesar-besarnya kemakmuran rakyat". Maka diperlukan kepatuhan dan kesadaran masyarakat dalam taat membayar pajak. Aturan dan tata cara perpajakan telah diatur sepenuhnya oleh Undang-Undang.

Perubahan sistem dari official assesment system menjadi self assesment system merupakan bukti kerjasama yang baik antara pemerintah dan masyarakat dimana pemerintah mempercayakan kepada masyarakat untuk mendaftar, menghitung, membayar dan melaporkan kewajiban perpajakannya sendiri, dengan demikian dituntut adanya kejujuran dan kesadaran masyarakat dalam melaporkan pajak. Tentu saja hal ini membawa dampak tersendiri bagi Pemerintah dimana fungsi pengawasan harus lebih dapat ditingkatkan dan aturan tegas harus dapat diberlakukan agar setiap masyarakat dapat melaporkan pajak dengan jujur dan benar.

Kepatuhan masyarakat tercermin dari kemauan masyarakat dalam melaporkan pajaknya tepat waktu. Kepatuhan perpajakan merupakan kepatuhan seseorang, dalam hal ini adalah wajib pajak, terhadap peraturan atau Undang-undang Perpajakan yang berlaku tanpa perlu diadakannya pemeriksaan, investigasi seksama, peringatan ataupun ancaman, dalam penerapan sanksi baik hukum maupun administrasi. Kepatuhan dan kesadaran dari wajib pajak merupakan dasar dari self assesment system. Objek dalam penelitian ini adalah orang pribadi yang terdaftar di KPP Pratama Medan Petisah.

Kesadaran perpajakan yang rendah merupakan salah satu masalah penyebab turunnya intensitas penerimaan pemerintah yang bersumber dari pajak. Kesadaran dalam hal ini adalah pengetahuan dan wawasan masyarakat mengenai peraturan perpajakan dan pentingnya pajak yang dibayarkan. Kesadaran perpajakan diukur berdasarkan seberapa jauh masyarakat taat dalam membayar pajak. Karena semakin tinggi antusiame masyarakat dalam membayar pajak semakin tinggi juga pengetahuan yang dimiliki masyarakat tentang pentingnya pajak yang ia bayarkan.

Kualitas pelayanan yang baik diharapkan mampu menarik minat masyarakat untuk taat dalam membayar pajak. Kualitas Pelayanan dalam hal ini dapat berupa interaksi secara langsung dan pengetahuan fiskus terhadap aturan dan tata cara perpajakan. Pelayanan fiskus dalam hal ini 
didasarkan pada Keputusan Menteri Pendayagunaan Aparatur Negara No. 63/KEP/M.PAN/7/2003, dimana dijelaskan bahwa "Pelayanan Publik adalah segala kegiatan pelayanan yang dilaksanakan oleh penyelenggara pelayanan publik sebagai upaya pemenuhan kebutuhan penerima pelayanan maupun pelaksanaan ketentuan peraturan perundang-undangan". Dengan demikian pelayanan publik yang dapat dikatakan baik apabila masyarakat dapat dengan mudah mendapatkan pelayanan dengan prosedur yang mudah, biaya murah, waktu yang cepat dan mendapat sedikit atau bahkan tidak ada keluhan dari masyarakat.

Sanksi adalah sebuah pemberian hukuman atas suatu tindakan yang dianggap melanggar hukum atau suatu aturan yang berlaku. Sanksi dalam hal ini sangat diperlukan untuk memberikan pelajaran dan efek jera bagi pelanggar pajak. Sanksi terbagi atas dua bagian yakni sanksi ringan yaitu berupa denda adminstrasi dan sanksi yang cukup berat yakni berupa tindak pidana yang ketentuannya telah diatur sepenuhnya dalam UndangUndang. Selama ini denda adminstrasi yang diberikan terhadap pelanggar wajib pajak sesuai dengan UU no 6 tahun 1983 pasal 7 dianggap cukup ringan sehingga masyarakat cenderung cuek dan tidak taat dalam membayar pajak. Dengan demikian, dengan adanya sanksi yang tegas diharapkan agar peraturan perpajakan dipatuhi sepenuhnya oleh masyarakat selaku para wajib pajak.

Penelitian ini bertujuan untuk mengetahui apakah sanksi pajak, kualitas pelayanan fiskus dan kesadaran perpajakan berpengaruh terhadap kepatuhan wajib pajak orang pribadi yang melaporkan SPT tahunannya di KPP Pratama Medan Petisah pada tahun 2011 hingga tahun 2014.

\section{TINJAUAN PUSTAKA DAN HIPOTESIS}

Pengertian pajak Berdasarkan UU KUP (Ketentuan Umum dan Tata Cara Perpajakan) NOMOR 28 TAHUN 2007 Pasal 1 ayat 1 disebutkan bahwa Pajak adalah kontribusi wajib kepada negara yang terutang oleh orang pribadi atau badan yang bersifat memaksa berdasarkan Undang-Undang, dengan tidak mendapatkan imbalan secara langsung dan digunakan untuk keperluan negara bagi sebesar-besarnya kemakmuran rakyat.

Berdasarkan hal di atas maka pajak mempunyai beberapa fungsi, berdasarkan UU KUP Nomor 28 yaitu: 


\section{- Fungsi anggaran (budgetair)}

Sebagai sumber pendapatan negara, pajak berfungsi untuk membiayai pengeluaran-pengeluaran negara. Untuk menjalankan tugastugas rutin negara dan melaksanakan pembangunan, negara membutuhkan biaya

\section{- Fungsi mengatur (regulerend)}

Pemerintah bisa mengatur pertumbuhan ekonomi melalui kebijaksanaan pajak. Dengan fungsi mengatur, pajak bisa digunakan sebagai alat untuk mencapai tujuan.

\section{- Fungsi stabilitas}

Dengan adanya pajak, pemerintah memiliki dana untuk menjalankan kebijakan yang berhubungan dengan stabilitas harga sehingga inflasi dapat dikendalikan, Hal ini bisa dilakukan antara lain dengan jalan mengatur peredaran uang di masyarakat, pemungutan pajak, penggunaan pajak yang efektif dan efisien.

\section{- Fungsi redistribusi pendapatan}

Pajak yang sudah dipungut oleh negara akan digunakan untuk membiayai semua kepentingan umum, termasuk juga untuk membiayai pembangunan sehingga dapat membuka kesempatan kerja, yang pada akhirnya akan dapat meningkatkan pendapatan masyarakat.

Undang-Undang No. 28 Tahun 2007 tentang perubahan ketiga atas Undang-Undang No. 6 Tahun 1983 mengenai Ketentuan Umum dan Tata Cara Perpajakan pada pasal 1 ayat (2) menjelaskan bahwa wajib pajak adalah orang pribadi atau badan, meliputi pembayar pajak, pemotong pajak, pemungut pajak, yang mempunyai hak dan kewajiban perpajakan sesuai dengan ketentuan peraturan perundang-undangan perpajakan.

\section{Wajib Pajak Orang Pribadi}

Setiap orang pribadi yang memiliki penghasilan di atas pendapatan tidak kena pajak. Di Indonesia, setiap orang wajib mendaftarkan diri dan mempunyai Nomor Pokok Wajib Pajak (NPWP), kecuali ditentukan dalam Undang-Undang.

\section{Wajib Pajak Badan}

Wajib Pajak Badan adalah sekumpulan orang dan/atau modal yang merupakan kesatuan baik yang melakukan usaha maupun yang tidak melakukan usaha yang meliputi perseroan terbatas, perseroan komanditer, perseroan lainnya, badan usaha milik negara atau badan usaha milik daerah dengan nama dan dalam bentuk apa pun, firma, kongsi, koperasi, 
dana pensiun, persekutuan, perkumpulan, yayasan, organisasi massa, organisasi sosial politik, atau organisasi lainnya, lembaga dan bentuk badan lainnya termasuk kontrak investasi kolektif dan bentuk usaha tetap.

\section{Wajib Pajak Bendaharawan}

Wajib Pajak Bendaharawan adalah Bendaharawan Pemerintah Pusat, Pemerintah Daerah, Instansi atau lembaga pemerintah, Lembaga Negara lainnya, dan Kedutaan Besar Republik Indonesia di Luar Negeri, yang membayar gaji, upah, tunjangan, honorarium dan pembayaran lain dengan nama apapun sehubungan dengan pekerjaan, jasa atau kegiatan.

Menurut Peraturan Menteri Keuangan RI No. 192/PMK.03/2007, kriteria Wajib Pajak Patuh adalah:

1. Tepat waktu dalam menyampaikan SPT untuk semua jenis pajak dalam tiga tahun terakhir.

2. Tidak mempunyai tunggakan pajak atau untuk semua jenis pajak, kecuali telah memperoleh izin untuk mengangsur atau menunda pembayaran pajak.

3. Tidak pernah dipidana karena melakukan tindak pidana di bidang perpajakan berdasarkan putusan pengadilan yang telah mempunyai kekuatan tetap dalam jangka waktu 5 (lima) tahun terakhir.

4. Dalam 3 tahun terakhir, menyusun laporan keuangan yang akan diaudit oleh Akuntan Publik atau lembaga pengawasan keuangan pemerintah, dalam bentuk panjang (long form report) dan menyajikan rekonsiliasi laba rugi komersial dan fiskal bagi Wajib Pajak yang wajib menyampaikan Surat Pemberitahuan Tahunan.

Pendapat Akuntan atas Laporan Keuangan yang diaudit oleh Akuntan Publik ditangani oleh Akuntan Publik yang tidak sedang dalam pembinaan lembaga pemerintah pengawas Akuntan Publik.

Menurut UU KUP Sanksi dapat dibagi 2 yakni :

\section{Sanksi Adminstrasi}

\section{A. Sanksi Denda}

Sanksi denda adalah jenis sanksi yang paling banyak ditemukan dalam UU Perpajakan. Pada sejumlah pelanggaran, sanksi denda ini akan ditambahkan dengan sanksi pidana. Pelanggaran yang dikenai sanksi pidana ini adalah pelanggaran yang sifatnya alpa atau disengaja. 
Pengenaan sanksi adminstrasi denda yang dikenakan kepada wajib pajak berbeda-beda sesuai pelanggaran yang terjadi pasal 7 ayat 1 (a) yakni wajib pajak yang terlambat menyampaikan SPT masa dikenakan denda sebesar Rp.100.000,00 atau Rp. 500.000 per SPT. Sedangkan untuk SPT tahunan menurut UU KUP pasal 7 ayat 1 (b) yakni wajib pajak dikenakan denda Rp.100.000,00 per SPT atau Rp. 1.000.000 per SPT.

\section{B. Sanksi Bunga}

Sanksi administrasi berupa bunga dikenakan atas pelanggaran yang menyebabkan utang pajak menjadi lebih besar. Jumlah bunga dihitung berdasarkan persentase tertentu dari suatu jumlah, mulai dari saat bunga itu menjadi hak/kewajiban sampai dengan saat diterima dibayarkan. Menurut UU KUP Pasal 8 disebutkan apabila wajib pajak terlambat menyampaikan SPT dapat dikenakan denda sebesar $2 \%$.

\section{Sanksi Pidana} apabila :

Pengenaan sanksi pidana dapat dikenakan kepada wajib pajak

\section{a. Setiap orang yang karena kealpaannya :}

1. Tidak menyampaikan Surat Pemberitahuan (SPT); atau

2. Menyampaikan SPT, tetapi isinya tidak benar atau tidak lengkap, atau melampirkan keterangan yang isinya tidak benar, sehingga dapat menimbulkan kerugian pada pendapatan negara, dipidana dengan pidana kurungan paling lama 1 (satu) tahun dan atau denda paling tinggi 2 (dua) kali jumlah pajak terutang yang tidak atau kurang dibayar.

\section{b. Setiap orang yang dengan sengaja :}

1. Tidak mendaftarkan diri, atau menyalahgunakan, atau menggunakan tanpa hak Nomor Pokok Wajib Pajak (NPWP) atau Pengukuhan Pengusaha Kena Pajak (PKP); atau

2. Tidak menyampaikan SPT; atau menyampaikan SPT dan atau keterangan yang isinya tidak benar atau tidak lengkap; atau menolak untuk dilakukan pemeriksaan; atau memperlihatkan pembukuan, pencatatan, atau dokumen lain yang palsu atau dipalsukan seolaholah benar.

sehingga dapat menimbulkan kerugian pada pendapatan Negara, di pidana dengan pidana penjara paling lama 6 (enam) tahun dan denda paling tinggi 4 (empat) kali jumlah pajak terutang yang tidak atau kurang dibayar.

Pengaruh Sanksi Pajak Terhadap Kepatuhan Wajib Pajak 
Kesadaran perpajakan masyarakat yang rendah seringkali menjadi salah satu sebab banyaknya potensi pajak yang tidak dapat dijaring. Kesadaran wajib pajak atas perpajakan amatlah diperlukan guna meningkatkan kepatuhan wajib pajak. Wajib pajak akan mematuhi pembayaran pajak bila memandang sanksi perpajakan akan lebih banyak merugikannya. Semakin banyak sisa tunggakan pajak yang harus dibayar wajib pajak, maka akan semakin berat bagi wajib pajak untuk melunasinya, dan keterlambatan dalam melunasinya akan dikenai sanksi. Oleh sebab itu sikap atau pandangan wajib pajak terhadap sanksi pajak diduga akan berpengaruh terhadap tingkat kepatuhan wajib pajak dalam membayar pajak.

\section{Pengaruh Pelayanan Fiskus Terhadap Kepatuhan Wajib Pajak}

Kepatuhan WP dalam memenuhi kewajibannya membayar pajak tergantung pada bagaimana petugas pajak memberikan mutu pelayanan yang terbaik kepada wajib pajak. Fiskus diharapkan memiliki kompetensi berupa keahlian (skill), pengetahuan (knowledge), dan pengalaman (experience) dalam hal kebijakan perpajakan, administrasi pajak dan perundang-undangan perpajakan. Selain itu fiskus harus memiliki motivasi yang tinggi sebagai pelayan publik. Oleh sebab itu kualitas pelayanan fiskus diduga akan berpengaruh terhadap kepatuhan wajib pajak.

\section{Pengaruh Kesadaran Perpajakan Terhadap Kepatuhan Wajib Pajak}

Kesadaran perpajakan sangat diperlukan guna meningkatkan kepatuhan pajak. Seseorang dikatakan memiliki kesadaran pajak antara lain apabila mengetahui adanya UU dan ketentuan perpajakan dan mau mematuhinya, mengetahui fungsi pajak untuk menyejahterakan rakyat, menghitung, membayar, melaporkan pajak tepat waktu dan secara sukarela tanpa paksaan. Sikap kesadaran yang tinggi mengenai pemahaman akan manfaat dan pentingnya pajak bagi kesejahteraan masyarakat dan dalam memajukan pembangunan daerah maupun pembangunan secara menyeluruh dapat mendorong seseorang untuk turut serta mewujudkan tanggung jawabnya dalam memenuhi kewajiban perpajakan, sehingga kepatuhan pajaknya dapat meningkat. Maka, semakin tinggi kesadaran perpajakan maka akan meningkatkan kepatuhan pajak.

Berdasarkan kerangka pemikirikan teoritis tersebut dapat digambarkan kerangka pemikiran teoritis sebagai berikut : 
Gambar 2.1.

Kerangka Pemikiran Teoritis

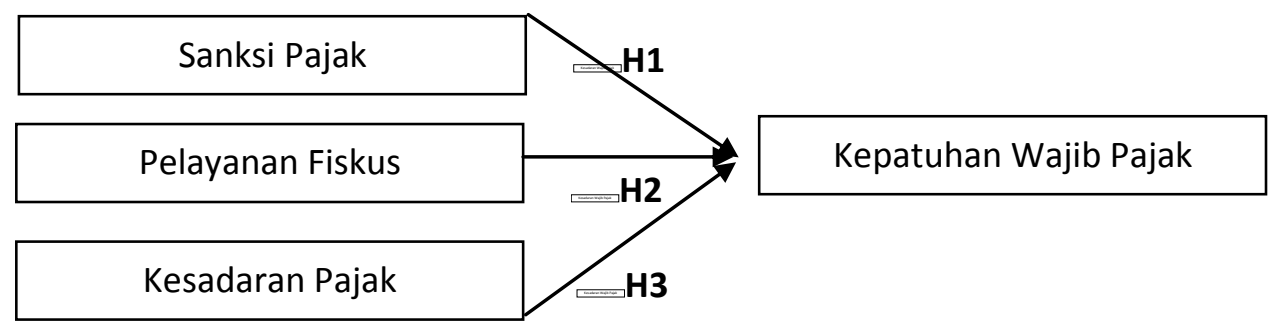

Hipotesis adalah jawaban sementara terhadap masalah yang masih bersifat praduga karena masih harus dibuktikan kebenarannya. Hipotesis merupakan jawaban sementara terhadap rumusan masalah penelitian. Dikatakan sementara karena jawaban yang diberikan baru didasarkan pada teori. Hipotesis dirumuskan atas dasar kerangka pemikiran teoritis yang merupakan jawaban sementara atas masalah yang dirumuskan.

Sanksi pajak juga diharapkan dapat membuat masyrakat dalam tertib membayar pajak. Sanksi pajak yang dikenakan kepada pelanggar pajak akan menimbulkan efek jera bagi para pelanggarnya. Adanya sanksi tersebut akan mendorong meningkatnya kepatuhan perpajakan. Hasil penelitian Kahono (2003), Suyatmin (2004), Jatmiko (2006), Suryadi (2006), dan Daroyani (2010) mengungkapkan bahwa sanksi berpengaruh positif dan signifikan terhadap kepatuhan. Semakin baik sanksi diberikan maka semakin tinggi pula kepatuhan perpajakan. Berdasarkan penjabaran di atas, maka diajukan hipotesis pertama sebagai berikut:

\section{H1 : Sanksi pajak berpengaruh positif dan signifikan terhadap kepatuhan pajak}

Kualitas pelayanan fiskus yang baik dan keramahtamahan petugas fikus juga dapat meningkatkan kepatuhan wajib pajak dalam membayar pajak. Kualitas pelayanan fiskus didasarkan pada SDM yang dimilikinya. Hasil penelitian Kahono (2003), Suyatmin (2004), Jatmiko (2006), Suryadi (2006), dan Daroyani (2010) mengungkapkan bahwa sikap fiskus berpengaruh positif dan signifikan terhadap kepatuhan perpajakan. Semakin baik sikap fiskus maka semakin tinggi pula kepatuhan 
perpajakan. Berdasarkan penjabaran di atas, maka diajukan hipotesis kedua sebagai berikut:

\section{H2 : Sikap fiskus berpengaruh positif dan signifikan terhadap kepatuhan pajak}

Sikap kesadaran masyarakat yang tinggi dapat mendorong masyarakat dalam meningkatkan kepatuhan wajib pajaknya . Hasil penelitian Suyatmin (2004), Jatmiko (2006), Suryadi (2006), Muliari dan Setiawan (2009), dan Daroyani (2010) mengungkapkan bahwa kesadaran perpajakan berpengaruh positif dan signifikan terhadap kepatuhan pajak. Berdasarkan penjabaran di atas, maka diajukan hipotesis ketiga sebagai berikut:

\section{H3 : Kesadaran perpajakan berpengaruh positif dan signifikan terhadap kepatuhan pajak}

\section{METODE PENELITIAN}

\subsection{Ruang Lingkup Penelitian}

Ruang lingkup dari penelitian ini adalah wajib pajak orang pribadi yang terdaftar di KPP Pratama Medan Petisah dengan menggunakan tiga (3) variabel independen dan satu (1) variabel dependen.

\subsection{Populasi dan Sampel}

Populasi adalah keseluruhan subjek penelitian. Populasi dalam penelitian ini adalah WP OP dan fiskus yang terdaftar di KPP Pratama Medan Petisah mulai dari tahun 2001 sampai dengan tahun 2015.

Sampel adalah sebagian dari keseluruhan individu yang menjadi objek penelitian. Sampel dalam penelitian ini adalah WP OP dan fiskus yang terdaftar di KPP Pratama Medan Petisah dari tahun 2011 hingga tahun 2014 sebanyak 100 orang.

\subsection{Teknik Analisis Data}

Teknik analisis data dalam penelitian ini menggunakan persamaan Regresi Berganda dengan bantuan Software SPSS 19. Sebelum melakukan analisis regresi, dilakukan uji validitas dan reliabilitas terhadap kuisioner. Serta uji asumsi klasik untuk menguji hubungan dan kecocokan antara variabel yang digunakan. Berikut persamaannya: 


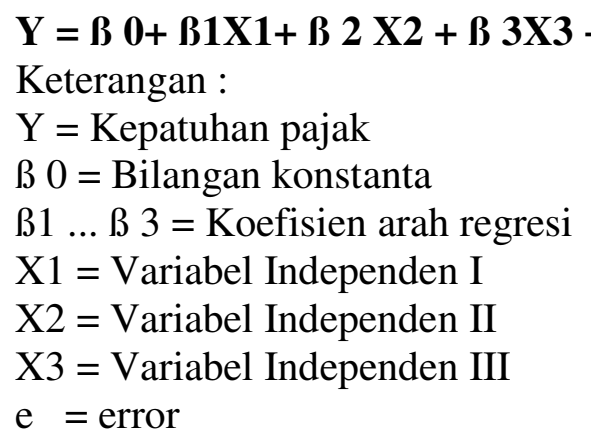

\section{HASIL PENELITIAN DAN PEMBAHASAN}

Penulis melakukan penelitian di KPP Pratama Medan Petisah dengan 100 orang responden wajib pajak orang pribadi.

\subsection{Hasil Pengujian}

\section{- Uji Validitas}

Kriteria yang digunakan untuk menyatakan suatu instrumen dianggap valid atau layak digunakan dalam pengujian hipotesis apabila Corrected Item-Total Correlation lebih besar dari 0,50. Hasil uji validitas pada penelitian ini adalah sebagai berikut:

\begin{tabular}{|c|c|c|c|}
\hline Variabel & Item & $\begin{array}{l}\text { Corrected Item- Total } \\
\text { Correlation }\end{array}$ & Ket. \\
\hline \multirow{6}{*}{$\begin{array}{l}\text { Sanksi Pajak } \\
\text { (X1) }\end{array}$} & $\mathrm{X} 1.1$ & 0,524 & Valid \\
\hline & $\mathrm{X} 1.2$ & 0,695 & Valid \\
\hline & $\mathrm{X} 1.3$ & 0,753 & Valid \\
\hline & X1.4 & 0,778 & Valid \\
\hline & X1.5 & 0,769 & Valid \\
\hline & X1.6 & 0,781 & Valid \\
\hline \multirow{6}{*}{$\begin{array}{c}\text { Pelayanan } \\
\text { Fiskus } \\
\text { (X2) }\end{array}$} & $\mathrm{X} 2.1$ & 0,643 & Valid \\
\hline & $\mathrm{X} 2.2$ & 0,520 & Valid \\
\hline & $\mathrm{X} 2.3$ & 0,548 & Valid \\
\hline & $\mathrm{X} 2.4$ & 0,620 & Valid \\
\hline & $\mathrm{X} 2.5$ & 0,721 & Valid \\
\hline & X2.6 & 0,709 & Valid \\
\hline \multirow{6}{*}{$\begin{array}{l}\text { Kesadaran } \\
\text { Perpajakan } \\
\quad \text { (X3) }\end{array}$} & X3.1 & 0,715 & Valid \\
\hline & X3.2 & 0,662 & Valid \\
\hline & X3.3 & 0,766 & Valid \\
\hline & X3.4 & 0,675 & Valid \\
\hline & X3.5 & 0,675 & Valid \\
\hline & X3.6 & 0,606 & Valid \\
\hline \multirow{2}{*}{$\begin{array}{c}\text { Kepatuhan WO } \\
\text { OP (Y) }\end{array}$} & Y.1 & 0,811 & Valid \\
\hline & Y.2 & 0,787 & Valid \\
\hline
\end{tabular}




\begin{tabular}{|c|c|c|c|}
\hline & Y.3 & 0,846 & Valid \\
\cline { 2 - 4 } & Y.4 & 0,847 & Valid \\
\cline { 2 - 4 } & Y.5 & 0,789 & Valid \\
\cline { 2 - 4 } & Y.6 & 0,813 & Valid \\
\hline
\end{tabular}

Sumber: Pengolahan Data SPSS IBM 19, 2015

Berdasarkan hasil uji validitas di atas, disimpulkan bahwa seluruh item pertanyaan yang digunakan dalam penelitian ini adalah valid.

\section{- Uji Reliabilitas}

Variabel dikatakan andal (reliable) jika memberikan nilai Cronbach's Alpha >0,50. Berdasarkan analisis uji reliabilitas menggunakan SPSS diperoleh hasil sebagai berikut:

\begin{tabular}{|c|c|c|}
\hline Variabel & Cronbach's Alpha & Ket. \\
\hline X1 & 0,894 & Reliabel \\
\hline X2 & 0,896 & Reliabel \\
\hline X3 & 0,877 & Reliabel \\
\hline Y & 0,937 & Reliabel \\
\hline
\end{tabular}

Sumber: Pengolahan Data SPSS IBM 19, 2015

Berdasarkan hasil uji reliabilitas di atas, maka dapat disimpulkan variabel-variabel yang digunakan dalam penelitian ini telah reliabel.

\section{- Hasil Uji Normalitas}

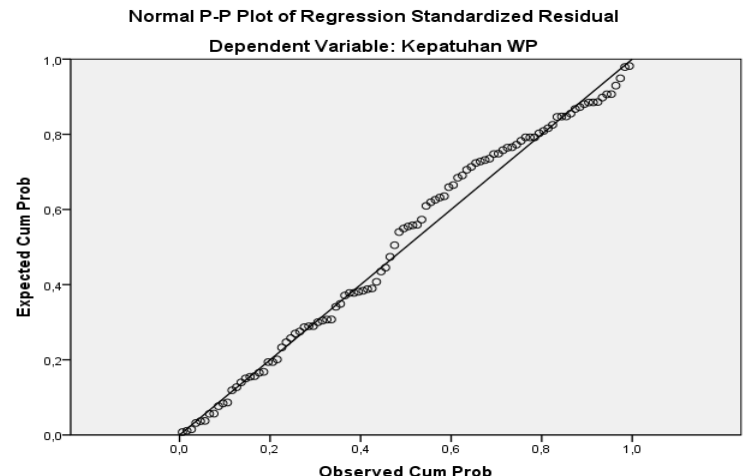

Output PP Plot Standardized Residual terlihat bahwa sebarannya mengikuti pola linier dan terlihat bahwa titik-titik menyebar di sekitar garis diagonal. maka data terdistribusi dengan normal sehingga dapat dikatakan model regresi data telah memenuhi asumsi normalitas. 


\section{- Hasil Uji Multikolonieritas}

\begin{tabular}{|c|c|c|}
\hline \multirow{2}{*}{ Model } & \multicolumn{2}{|c|}{ Collinearity Statistics } \\
\cline { 2 - 3 } & Tolerance & VIF \\
\hline X1 & 0,660 & 1,515 \\
\hline X2 & 0,768 & 1,303 \\
\hline X3 & 0,671 & 1,491 \\
\hline
\end{tabular}

Berdasarkan hasil penelitian diatas dapat disimpulkan bahwa tidak ada variabel bebas yang memiliki nilai tolerance kurang dari 0,10 . Hasil uji VIF juga menunjukan hal yang sama yaitu tidak ada satupun variabel independen yang memiliki VIF lebih dari 10. Jadi dapat disimpulkan bahwa tidak ada multikolinieritas antar variabel independen dalam model regresi atau uji multikolinieriatas sudah terpenuhi.

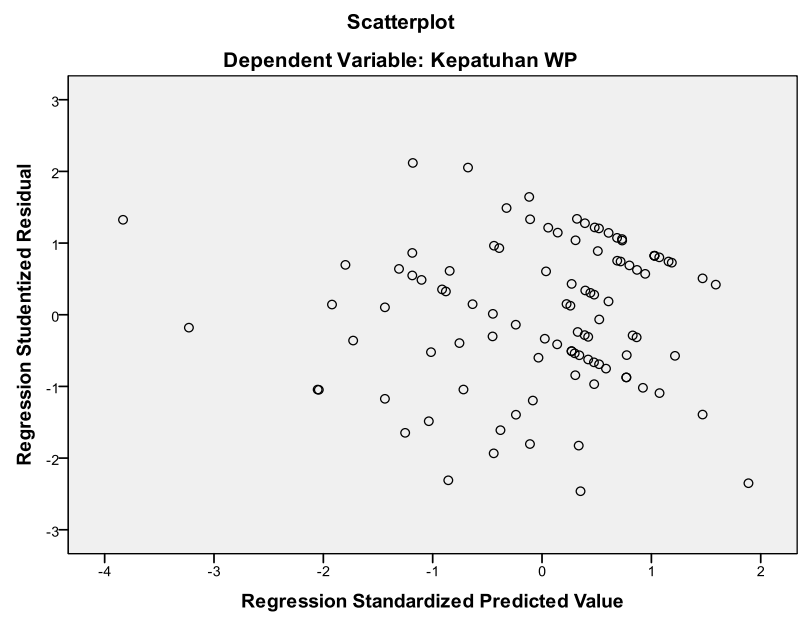

Sumber: Pengolahan Data SPSS IBM 19, 2015

\section{- Hasil Uji Heteroskedastisitas}

Berdasarkan di atas, dapat diketahui bahwa data (titik-titik) menyebar secara merata di atas dan di bawah garis nol, tidak berkumpul di satu tempat, serta tidak membentuk pola tertentu sehingga dapat disimpulkan bahwa uji regresi ini tidak terjadi masalah heteroskedastisitas. 


\subsection{Pengujian Hipotesis dan Pembahasan}

Coefficients

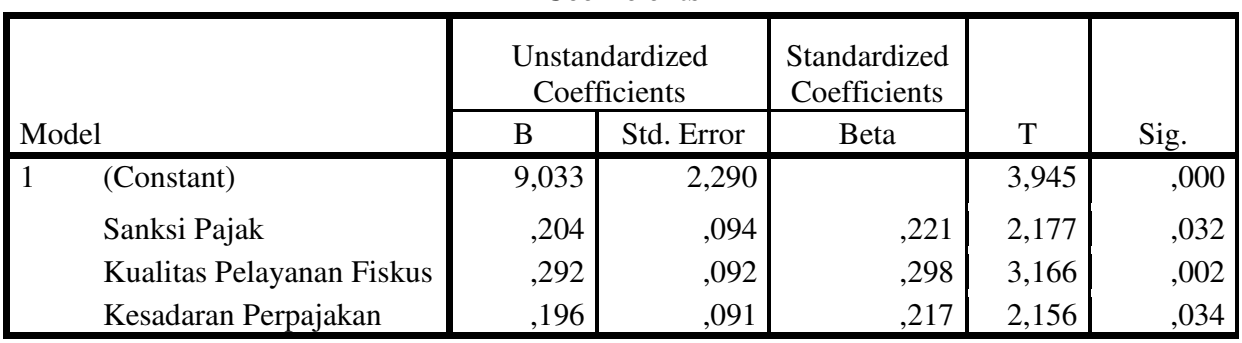

a. Dependent Variable: Kepatuhan WP

$$
Y=9,033+0,204(X 1)+0,292(X 2)+0,196(X 3)+E
$$

1. Untuk variabel sanksi pajak (X1) diperoleh koefisien regresi dengan arah positif sebesar 0,204. Hal ini berarti bahwa pengaruh antara variabel Sanksi pajak dengan variabel kepatuhan wajib pajak adalah positif. sanksi pajak memiliki nilai sig. sebesar 0,032 dimana 0,032 <0,05 dan nilai $t_{\text {hitung }} 2,177>$ $\mathrm{t}_{\text {tabel }} 1,985$, sehinggga H0 ditolak dan Ha diterima. Dengan demikian, dapat diambil kesimpulan bahwa variabel Sanksi Pajak mempunyai pengaruh positif dan signifikan terhadap kepatuhan wajib pajak pada KPP Pratama Medan Petisah.

2. Untuk variabel kualitas pelayanan fiskus (X2) diperoleh koefisien regresi dengan arah positif sebesar 0,292. Hal ini berarti bahwa pengaruh antara variabel kualitas pelayanan fiskus dengan variabel kepatuhan wajib pajak adalah positif . Kualitas Pelayanan fiskus memiliki nilai sig. sebesar 0,002 dimana $0,002<0,05$ dan nilai $t_{\text {hitung }} 3,166>t_{\text {tabel }} 1,985$, sehinggga Ho ditolak dan Ha diterima. Dengan demikian, dapat diambil kesimpulan bahwa variabel kualitas pelayanan fiskus mempunyai pengaruh positif dan signifikan terhadap kepatuhan wajib pajak pada KPP Pratama Medan Petisah.

3. Untuk variabel kesadaran perpajakan (X3) diperoleh koefisien regresi dengan arah positif sebesar 0,196 . Hal ini berarti bahwa pengaruh antara variabel kesadaran perpajakan dengan variabel kepatuhan wajib pajak adalah positif . Kesadaran perpajakan memiliki nilai sig. sebesar 0,034 dimana 0,034 $<0,05$ dan nilai $t_{\text {hitung }} 2,156>t_{\text {tabel }} 1,985$, sehinggga Ho ditolak dan Ha diterima. Dengan demikian, dapat diambil kesimpulan bahwa variabel kesadaran perpajakan mempunyai pengaruh positif dan signifikan terhadap kepatuhan wajib pajak pada KPP Pratama Medan Petisah. 


\begin{tabular}{|ll|r|r|r|r|c|}
\hline \multicolumn{7}{|c|}{ ANOVA $^{\mathbf{b}}$} \\
\hline \multicolumn{1}{|l|}{ Model } & \multicolumn{1}{|c|}{$\begin{array}{l}\text { Sum of } \\
\text { Squares }\end{array}$} & \multicolumn{1}{c|}{ df } & Mean Square & F & Sig. \\
\hline 1 & Regressio & 529,865 & 3 & 176,622 & 16,987 &, $000^{\mathrm{a}}$ \\
& $\mathrm{n}$ & & & & \\
& Residual & 998,135 & 96 & 10,397 & & \\
& Total & 1528,000 & 99 & & & \\
\hline
\end{tabular}

a. Predictors: (Constant), Kesadaran Perpajakan, Kualitas Pelayanan Fiskus, Sanksi Pajak

b. Dependent Variable: Kepatuhan WP

Berdasarkan Tabel 4.13 menunjukkan bahwa nilai sig dari model penelitian ini adalah sebesar 0,000 dimana nilai $0,000<0,05$ dan $F_{\text {hitung }} 16,987>F_{\text {tabel }} 2,699$ Berdasarkan hasil tersebut maka dapat disimpulkan bahwa Ha diterima dan Ho ditolak. Hal ini menunjukkan bahwa terdapat hubungan antara variabel independen dengan variabel dependen. Artinya pengaruh sanksi pajak, kualiatas pelayanan fiskus dan kesadaran perpajakan secara bersama-sama mempunyai pengaruh signifikan terhadap kepatuhan wajib pajak pada KPP Pratama Medan Petisah.

\section{KESIMPULAN DAN SARAN}

\subsection{Kesimpulan}

Berdasarkan hasil analisis dan pembahasan yang telah dilakukan yaitu mengenai pengaruh sanksi pajak, kualitas pelayanan fiskus, dan kesadaran perpajakan terhadap kepatuhan wajib pajak orang pribadi maka dapat diberikan kesimpulan sebagai berikut.

1. Persamaan regresi linear berganda yang diperoleh adalah $\mathrm{Y}=9,033+0,204$ $\mathrm{X} 1+0,292 \mathrm{X} 2+0,196 \mathrm{X} 3+\mathrm{e}$. Artinya sanksi pajak, kualitas pelayanan fiskus, dan kesadaran perpajakan memiliki pengaruh positif dan signifikan terhadap Kepatuhan Wajib Pajak orang pribadi pada KPP Pratama Medan Petisah. Hal ini dapat dilihat dari koefisien regresinya.

2. Berdasarkan hasil pengujian hipotesis untuk variabel sanksi pajak, diperoleh koefisien regresi dengan arah positif 0,204 dan nilai sig. sebesar 0,032 dimana $0,003<0,05$ dan nilai $t_{\text {hitung }} 2,177>t_{\text {tabel }} 1,985$. Hal tersebut menunjukkan bahwa secara parsial variabel sanksi pajak mempunyai pengaruh positif dan signifikan terhadap variabel kepatuhan wajib pajak.

3. Berdasarkan hasil pengujian hipotesis untuk variabel kualitas pelayanan fiskus, diperoleh koefisien regresi dengan arah positif 0,292. dan nilai sig. sebesar 0,002 dimana $0,002<0,05$ dan nilai $t_{\text {hitung }} 3.166>t_{\text {tabel }} 1,985$. Hal tersebut menunjukkan bahwa secara parsial variabel kualitas pelayanan fiskus mempunyai pengaruh positif dan signifikan terhadap variabel kepatuhan wajib pajak. 
4. Berdasarkan hasil pengujian hipotesis untuk variabel kesadaran perpajakan, diperoleh koefisien regresi dengan arah positif 0,196 . dan nilai sig. sebesar 0,034 dimana $0,034<0,05$ dan nilai $\mathrm{t}_{\text {hitung }} 2,156>\mathrm{t}_{\text {tabel }} 1,985$. Hal tersebut menunjukkan bahwa secara parsial variabel kesadaran perpajakan mempunyai pengaruh positif dan signifikan terhadap variabel kepatuhan wajib pajak.

5. Berdasarkan uji $\mathrm{F}$ diperoleh nilai sig sebesar 0,000 dimana nilai $0,000<$ 0,05 dan $\mathrm{F}_{\text {hitung }} 16,987>\mathrm{F}_{\text {tabel }} 2,699$. Hal tersebut menunjukkan variabel sanksi pajak kualitas pelayanan fiskus dan kesadaran perpajakan secara simultan mempunyai pengaruh positif dan signifikan terhadap kepatuhan wajib pajak.

6. Kemampuan persamaan regresi ini untuk menjelaskan besarnya variasi yang terjadi dalam variabel terikat adalah sebesar $34,7 \%$, sementara $65,3 \%$ dijelaskan oleh variabel lain yang tidak dipergunakan dalam persamaan regresi ini.

\subsection{Saran}

Saran yang dapat diberikan sehubungan dengan hasil penelitian yang dilakukan adalah sebagai berikut :

1. Sanksi pajak harus disosialisasikan dengan baik kepada para wajib pajak agar wajib pajak dapat memahami hal-hal yang berkaitan dengan pelaksanaan sanksi pajak serta penyebab-penyebab dikenakannya suatu sanksi pajak terhadap wajib pajak. Sosialisasi ini dapat dilakukan dengan memberikan penyuluhan secara gratis bagi para wajib pajak baru atau secara berkala mengirimkan pemberitahuan mengenai pelaksanaan sanksi pajak.

2. Fiskus harus bertindak profesional dalam melayani para wajib pajak dengan sebaik-baiknya. Pihak Direktorat Jenderal Pajak dapat melakukan pelatihan pelayanan wajib pajak agar dapat meningkatkan pelayanan fiskus kepada wajib pajak. Fiskus juga diseleksi dengan ketat sesuai dengan bidang keahlian yang dibutuhkan agar fiskus benar-benar cakap dalam melakukan tugasnya.

3. Perlu disosialisasikan sikap sadar membayar pajak di masyarakat. Sosialisasi ini dapat melalui iklan di televisi, radio maupun surat kabar serta media lainnya. Sosialisasi yang terus menerus dilakukan diharapkan dapat menggali kesadaran masyarakat akan pentingnya pajak bagi pemerintah.

\section{DAFTAR PUSTAKA}

Azwar (2001) Aplikasi Analisis Multivariate dengan Program SPSS. Edisi Ketiga. Semarang: Badan Penerbit UNDIP.

Augusty, Ferdinand. 2006. Metode Penelitian Manajemen. Semarang: Badan Penerbit Universitas Diponegoro. 
Azwar, Syaifuddin. 2005. Reliabilitas dan Validitas : Interprestasi dan Komputasi. Yogyakarta: Liberty

Agus N.Jatmiko (2006), Pengaruh Sikap Wajib Pajak Pada Pelaksanaan Sanksi Denda, Pelayanan Fiskus dan Kesadaran Perpajakan Terhadap Kepatuhan Wajib Pajak (Studi Empiris Terhadap Wajib Pajak Orang Pribadi di Semarang). Tesis Program S2 Magister Akuntansi Universitas Diponegoro. Tidak Dipublikasikan. Parasuraman (2000)

Chaizi Nasucha, 2004, Reformasi Administrasi Publik. Jakarta: PT. Grasindo Santoso .

Gibson, James L, John M Ivancevich, James H. Donnely Jr. 2000. Organization:Behavior, Structure, Processes. England: Irwin Inc.

Kiryanto,2000. Analisis Pengaruh Penerapan Struktur Pengendalian Intern Terhadap Kepatuhan Wajib Pajak Dalam Memenuhi Kewajiban Pajak Penghasilannya, EKOBIS, Vol. 1 No. 1, p. 41 - 52. Nurmantu (2003) .

Karim, Abdul .2008. Perilaku Wajib Pajak Dalam Pelunasan Tunggakan Pajak dan Implementasi Penagihan aktif di Kantor Pelayanan Pajak. Jakarta: Universitas Indonesia.

Muljono, Djoko .2008. Pajak Pertambahan Nilai. Yogyakarta: Cv Andi.

Muliari dan Setiawan. 2009. Faktor-Faktor yang Mempengaruhi Kemauan untuk Membayar Pajak Wajib Pajak Orang Pribadi yang Melakukan Pekerjaan Bebas (Studi Kasus pada KPP Pratama Denpasar). Simposium Nasional Akuntansi XII.Denpasar Bali.

Nowak, Norman D. 2004. Tax Administration in Theory and Practice. New York : Praeger Publisher.

Robbins, Stephen P. 2001. Perilaku Organisasi, Edisi 8. Prentice Hall, Jakarta.

Supriyati dan Hidayati. 2008. Pengetahuan Pajak dan Persepsi Wajib Pajak Terhadap Kepatuhan Wajib Pajak, Jurnal Akuntansi dan Teknologi Informasi. Vol. 7 No 1.

Suyatmin (2004) PENGARUH SIKAP WAJIB PAJAK TERHADAP KEPATUHAN WAHB PAJAK DALAM PEMBAYARAN PAJAK STUDI EMPIRIS DI WILAYAH KP.PBB S(JRAKARTA). Masters thesis, Program Pascasarjana Universitas Diponegoro.

UU KUP NOMOR 28 TAHUN 2007. Tentang Perubahan dan Ketentuan tata Cara Perpajakan

Wirawan B. Ilyas dan Burton, Richard .2004. Hukum Pajak. Edisi 5. Buku 1. Salemba Empat. Jakarta.

Zain, Mohamad. 2007. Manajemen Perpajakan. Edisi Buku 3. Penerbit Salemba Empat,Jakarta 